\title{
Protection of the Environment and the International Salvage Convention, 1989: An Assessment
}

\begin{abstract}
This article focuses on the International Salvage Convention and the protection of the environment in salvage operations. The article traces the evolution and history of the law of Salvage to its present status by using the UK as a case study. In essence, the article seeks to ascertain the extent of current international regime on salvage in protecting the environment. The question that this article poses is: Does the International Salvage Convention 1989 accord enough protection to the environment against the backdrop of global efforts to promote environmental protection and sustainable development? The article begins with a brief synopsis of the underlying principles of salvage including the rule of 'no cure-no pay' followed by an appraisal of the events that culminated arguably in the development of the International Salvage Convention 1989 to safeguard the environment in the course of salvage operations. A systematic analysis of the defects inherent in the International Salvage Convention 1989 vis-à-vis protection of the environment are analysed and a number of reforms are highlighted.
\end{abstract}

Eghosa O. Ekhator *

\section{Key terms}

International Salvage Convention, England, Environmental Protection, Pollution and Environmental Salvage Award

DOI

http://dx.doi.org/10.4314/mlr.v10i1.3

\section{Introduction}

This article focuses on the International Salvage Convention and the protection of the environment in salvage operations. The article traces the evolution and history of the law of Salvage to its present status, and it uses the UK as a case study. The article seeks to ascertain the extent of current international regime on salvage in protecting the environment. The first section focuses on the history and evolution of salvage. The modern concept of salvage which can traced to the United Kingdom (hereinafter 'UK'), ${ }^{1}$ (especially England) hence the city of

\footnotetext{
* Eghosa Osa Ekhator, PhD (Hull), LL.M (Hull), LL.B (Benin); barrister and solicitor of the Supreme Court of Nigeria.

${ }^{1}$ The origins of salvage are ancient and existed in old legal systems such as the Roman epoch amongst others. The Law of Salvage's core principles were established in the nineteenth century and the Admiralty Courts in England played major roles in the modern
} 
London occupy special place in the international salvage paradigm. The second section briefly discusses the subject matter of salvage. Definitions of terms such as 'vessel', 'ship' or 'maritime property' will be elucidated upon. A major reason for focusing on these definitions is to highlight the evolution of the different meanings ascribed to these terms.

The third section highlights the three core elements of the law of salvage: danger, voluntariness and success. Section 4 focuses on environmental protection in salvage operations. Many salvage operations have had negative impacts on the environment, thus, this section highlights the role of the International Salvage Convention $1989^{2}$ in protecting the environment. The fifth section suggests some reforms to improve protection of the environment in the international salvage paradigm. The article also considers if the development of a separate environmental salvage award can be the panacea to some of the weaknesses in environmental protection in salvage operations.

\section{The History and Evolution of Salvage}

Salvage is traditionally concerned with the salving or preservation of property in peril at sea ${ }^{3}$ and it is unique to maritime law. If a person willingly rescues the property of another person on land, he gets no reward. However, if the same service is performed at sea, the person salving the maritime property, the 'salvor', will be entitled to a reward, not exceeding the value of the property salved. ${ }^{5}$ Salvors are provided special incentives in addition to the compensation

development of the law of Salvage. Generally, see Olivia Lennox-King (2007) 'Laying the Mark to Port and Starboard: Salvage under duress and Economic duress at Contract Law' 21 Australian \& New Zealand Maritime Law Journal 31, 32; Catherine Swan (2009) 'The Restitutionary and Economic Analyses of Salvage Law' 23 Australian \& New Zealand Maritime Law Journal 99. See also George F. Steckley (2014) 'The SeventeenthCentury Origins of Modern Salvage Law' 35(3) The Journal of Legal History 209. Thus, some scholars aver that the 'first recorded salvage dispute dates from 1601'. See YinCheng Hsu (2016) 'Developments in International Cultural Heritage Law: What Hampers the Convention on the Protection of the Underwater Cultural Heritage.' 3 Edinburgh Student Law Review 116, p. 125.

${ }^{2}$ International Convention on Salvage, 1989. Drafted by the Comite Maritime International (CMI) under the auspices of the International Maritime Organisation (IMO). Also referred to as the Salvage Convention 1989 or the London Salvage Convention.

$<$ http://www.jus.uio.no/lm/imo.salvage.convention.1989/doc.html $>$ accessed 1 January 2015.

${ }^{3}$ Geoffrey Brice (2003) Brice on Maritime Law of Salvage (4 ${ }^{\text {th }}$ edn, Sweet and Maxwell) 397.

${ }^{4}$ Ibid.

5 Simon Baughen (2012) Shipping Law (5 ${ }^{\text {th }}$ edn, Routledge) p. 274. However, under Article $8(1)$ (c) and (d) of the 1989 Convention a salvor, in appropriate circumstances, is required to seek assistance and accept the intervention of other salvors'. 
due to them because of the risks taken in coming to a distressed ship's aid. Kennedy defined salvage in the same vein. ${ }^{6}$ Brice $^{7}$ defined salvage as a right which:

arises when a person acting as a volunteer (that is, without any pre - existing contractual or other legal duty so to act) preserves or contributes to preserving at sea any vessel, cargo, freight or other recognised subject of salvage from danger. ${ }^{8}$

In the law of salvage, no matter the efforts of the salvor, if the endeavour is unsuccessful, no reward is given. This is the legal reasoning behind the 'no cure-no pay' doctrine. According to Mandaraka-Sheppard, 'the right to reward, rather than remuneration, arises from the fact that salvage is a mixed question of a private right and public policy'.

The framework of the current law on salvage was first established by the decisions of the Admiralty Court in the UK in the eighteenth and nineteenth centuries. ${ }^{10}$ During this time, salvage was purely voluntary and more often than not, 'often non-contractual, rendered by ordinary ships that happened to be passing the distressed ship. ${ }^{11}$ Thus, prior to the end of the nineteenth century, express salvage contracts were unknown. ${ }^{12}$

Presently, salvage is mainly performed by trained or professional salvors that are usually contracted for their services. In the eighteenth and nineteenth centuries, a unique form of contract - Lloyd's Open Form (hereinafter 'LOF') evolved and it coincided with the substantial usage of steamships and tugs. ${ }^{13}$

${ }^{6}$ DW Steel and Rose FD (1985) Kennedy's Law of Salvage $\left(5^{\text {th }}\right.$ edn, Steven and Sons)p. 8.

${ }^{7}$ Brice (2003) supra note 3, p. 1.

${ }^{8}$ Ibid.

${ }^{9}$ Aleka Mandaraka-Sheppard Modern Admiralty Law (1 $1^{\text {st }}$ edn, Cavendish) 650. According to Richard Shaw \& MikisTsimplis (2011) 'The Liabilities of the Vessel' in Yvonne Baatz (ed), Maritime Law (2nd edn, Sweet \& Maxwell 2011) pp. 250-251, who posit that the public policy in salvage operations encompasses three elements -'first, recognising that such assistance entitles the salvors of the property to a salvage reward; second, that the right to a salvage reward arises at the time of rendering assistance irrespective of any contract; and third, that this right is protected by a maritime claim of the highest priority, the salvage lien, and a right to arrest the salved property by an action in rem.'

${ }^{10}$ Baughen, supra note 5, p. 275.

${ }^{11}$ Ibid.

12 Id., p. 651.

${ }^{13}$ The LOF is a type of contract that is widely used in the international salvage industry. It contains the 'No Cure-No Pay' principle in salvage operations. The first LOF was approved in 1892 and it has been used in the salvage industry for more than one hundred years. Generally, the LOF provides for England as the appropriate forum for litigation and London for arbitration. However, different types of salvage contracts exist in other parts of the world, for example, China, Russia and Japan. See Graham Daines, (2002) 
Salvage agreements became more common, and by the nineteenth century, a Lloyd's Form of Salvage Agreement 'No Cure - No Pay'- (sometimes known as 'Lloyd's Standard Form' or 'Lloyd's Open Form') first came to be used, soon to be superseded and improved during the course of the twentieth century, culminating in 'LOF 2000. ${ }^{14}$ Furthermore, in 2011, the LOF underwent some changes and this is reflected in LOF 2011. ${ }^{15}$ In The Unique Mariner, Brandon J said that the LOF contract has been judicially categorised as one for work or labour which is only subject to the principles of Salvage law in so far as these have been expressly or impliedly incorporated into it. ${ }^{16}$ Here, in non-contractual (implied) salvage,

The salvor and salvee owe only minimal duties towards one another. The salvor owes a duty of care in respect of any services that it actually performs, but it owes no duty to perform those services. It is free to cease work at any time it chooses. ... The position is quite different with a contractual salvor. ... LOF imposes an additional duty on the salvor to use its best endeavours to salve the ship and its cargo. ${ }^{17}$

The LOF is the most widely used 'no cure - no pay' salvage contract. Under a LOF contract, in return for salvage services, the salvor receives a proportion of the 'salved value' (the value of ship, its bunkers and cargo). ${ }^{18} \mathrm{~A}$ major distinction between the LOF and the traditional principles of salvage is that 'under the LOF, salvage is admitted, thereby obviating the need for the salvor to show that the vessel was in danger at the time that the agreement was made. ${ }^{, 19}$ As highlighted above, there have been various updates of the LOF culminating in the LOF 2011. The LOF 1980 was the impetus for the development of the 1989 International Salvage Convention. ${ }^{20}$ The LOF contained provisions on environmental risks and protection in salvage operations and these provisions were added to the 1989 Convention. In essence, the LOF protects salvors from the hazards or risks inherent in salvage operations by providing them with incentives (such as financial incentives) to balance their losses.

'Lloyd's Open Form and Special Compensation P \& I Clause (SCOPIC)' $<$ http://www.comitemaritime.org/Uploads/Salvage\%20Convention/Graham\%20Daines\% 20-\%20Scopic\%20Paper.pdf $>$. Accessed 10 February 2015.

14 Brice, supra note 3, p. 5.

15 Baughen, supra note 5. The changes inherent in the LOF 2011 will be analysed in a subsequent section of this article.

${ }^{16}$ The Unique Mariner (No 2) [1979] I Lloyd's Rep 37.

${ }^{17}$ Baughen, supra note 5, p. 294.

${ }^{18}<\mathrm{http}$ //www.marine-salvage.com/overview/index.asp?page=no_cure_no_pay.htm> accessed 2 January 2015.

${ }^{19}$ Baughen, supra note 5, p. 274.

${ }^{20}$ Ibid. 


\section{The Subject Matter of Salvage}

Prior to the development of the International Salvage Convention 1989, the subject matter of 'salvage' as found in English law was vague and ambiguous. For example, section 742 of the 1894 Merchant Shipping Act (now abolished) ${ }^{21}$ defined a 'vessel' to 'include any ship or boat, or any other description of vessel used in navigation not propelled by oars.' According to Mandaraka-Sheppard, this definition was circular and she avers that the definition which entails 'that a vessel includes a ship and a ship includes a vessel does not help much by way of definition'. ${ }^{22}$ Thus, this definition of a ship as encapsulated in the Merchant Shipping Act 1894 was ambiguous and was subjected to diverse meanings or interpretations.

For example, in The Gas Float Whitton (No.2) ${ }^{23}$ this concerned a structure that was shaped like a ship. The House of Lords held that the structure was not a ship within the meaning of the Merchant Shipping Act 1894 and also that a salvage reward is not available to any person in respect of anything that is not a ship, part of a ship or cargo. Marsden criticised this judgment on the basis of it not being in accordance with the practice of the Admiralty courts which had prevailed for at least three centuries prior to the judgment. ${ }^{24}$ The decision in The Gas Float Whitton (No. 2) is an example of the effect of ambiguity contained in the definition of 'vessel' in the 1894 Merchant Shipping Act.

This definition of a vessel has been now discarded. The phrase 'not propelled by oars' has been omitted from the definition of a 'ship.' It was removed by virtue of the Merchant Shipping (Registration) Act $1993,{ }^{25}$ enacted into the Merchant Shipping Act $1995 .{ }^{26}$ Section 313(1) of the latter Act defines a ship to include any vessel used in navigation. The International Salvage Convention $1989^{27}$ defines a ship in Article 1(b) to include any ship, craft or any structure capable of navigation.

Other types of traditional maritime property that can be subject to salvage are freight and cargo. Cargo is subject to salvage irrespective of whether it is owned by a ship owner or by a third party or whether or not it is carried under a bill of lading. ${ }^{28}$ In the Gas Float Whitton (No.2), cargo was held to qualify as a subject

${ }^{21}$ The Merchant Shipping Act 1894.

${ }^{22}$ Mandaraka-Sheppard, supra note 9, p. 15.

${ }^{23}$ [1897] AC 339.

${ }^{24}$ RG Marsden (1899) ‘Admiralty Droits and Salvage-Gas Float Whitton No. II’ L.Q.R 353, p. 354.

${ }^{25}$ The Merchant Shipping (Registration) Act 1993.

${ }^{26}$ Mandaraka-Sheppard, supra note 9.

${ }^{27}$ Supra note 2 .

${ }^{28}$ Baughen, supra note 5. 
matter of salvage. ${ }^{29}$ Article 1(c) of the International Salvage Convention 1989 defines a maritime property as any property not permanently and intentionally attached to the shoreline and includes freight at risk. This includes goods or merchandise on ships but it is not inclusive of the personal effects of master (or crew) and passengers. Article 1(c) of the International Salvage Convention ${ }^{30}$ makes freight subject to salvage. Freight is the remuneration due and payable for the carriage of cargo and not hire for the use of ships. ${ }^{31}$ Also, "cargo adrift or sunken ships' (ship wrecks) is likewise subject to the law of Salvage. ${ }^{32}$

Non-maritime property can also be subject to the law of Salvage. Generally, an aircraft cannot be termed a maritime property but it maybe entitled to salvage under Section 87(1) of the Civil Aviation Act 1982. ${ }^{33}$ Similarly, this treatment is also extended to hovercrafts by virtue of Sections 1 and 2 of the Hovercraft Act $1968 .{ }^{34}$ Here, ships, hovercrafts and other similar structures capable of navigation or movement and other such property that are not permanent fixtures on shores are subject to the law of Salvage. ${ }^{35}$

As a general rule, platforms and drilling units are not subject to salvage by virtue of Article 3 of the Salvage Convention 1989. ${ }^{36}$ However, there are a few exceptions to this rule. When such structures are engaged in the act of drilling, the law of Salvage is not applicable to such structures; however when such platforms or drilling units are in navigation, they become subject to the law of Salvage. ${ }^{37}$

Furthermore, by virtue of Article 4, of Schedule 11 of the Merchant Shipping Act $1995,{ }^{38}$ the International Salvage Convention $1989^{39}$ does not apply to warships or non-commercial vessels owned or operated by a country or State and entitled at the time of salvage operations to sovereign immunity under international law unless that State allows it. In the UK, Section 230 of the Merchant Shipping Act 1995 deals with salvage claims by or against the Crown.

${ }^{29}$ (No.2) [1897] A.C 339.

${ }^{30}$ Baughen, supra note

${ }^{31}$ Mandaraka-Sheppard, supra note 9, p. 660.

${ }^{32}$ Institute of Maritime Law (2008) Southampton on Shipping Law (Informa Law) 163.

${ }^{33}$ The Civil Aviation Act 1982. Also, in respect of saving of lives at sea, 'will not, by itself justify a claim for salvage if it is not connected with the salvage of some maritime property' Baughen, supra note 5, p. 277. Also see Ethan Zubic (2010-2011) 'Pure versus Contract Salvage-Narrowing the Scope of an Agreement to Volunteer Bar to Pure Salvage.' 10 Loyola Maritime Law Journal 145, 149-15

${ }^{34}$ The Hovercraft Act 1968.

${ }^{35}$ Institute of Maritime Law, supra note 32.

${ }^{36}$ Supra note 2.

${ }^{37}$ Institute of Maritime Law, supra note 32.

${ }^{38}$ Merchant Shipping Act 1995.

${ }^{39}$ Supra note 2. 


\section{Elements of Salvage}

The principal elements of salvage are threefold: danger, voluntariness and success. $^{40}$

\subsection{Danger}

Before, any ship or vessel at sea can be subject to salvage, the ship must be in danger. The danger which may be actual or a likelihood of real danger must expose the property to the possibility of damage. An apprehension of danger will suffice as long it is not a fanciful danger and it does not have to be immediate or absolute. ${ }^{41}$ In the Phantom, Lord Lushington stated, inter alia, that - 'it is not necessary that there should be absolute danger in order to constitute salvage services, it is sufficient if there is a state of difficulty, and reasonable apprehension' ${ }^{42}$

Danger can be categorised into future or contingent danger and danger to third parties or the environment. Future danger is known as the 'Troilus danger'. In the Troilus case, a steamship carrying cargo to Liverpool lost her propeller in the Indian Ocean, and therefore accepted assistance from a motor-vessel which towed her to safety to Aden where unfortunately she could not be repaired and where there were no facilities for discharging and storing the cargo. ${ }^{43}$ The court held that although the ship and cargo were in physical safety at Aden, the services in question were salvage services.

In the case of a danger to third parties, the salvor can claim a reward if he successfully prevents damage affecting the interests of a third party. If a salvor successfully saves a maritime property and at the same time helps in reducing the damage that would have been caused to a third party, he is entitled to a reward from the salvee (the owner of the vessel).

In the area of danger to the environment, Article 1(d) of the Salvage Convention states thus:

40 Some authors contend that there are more than three principles or elements of salvage. Herein, the principles or ingredients of salvage (under customary international law) are danger, voluntariness, success, place of rendering the services and the type of property salved. For example, see William Tetley (1998)Maritime Liens and Claims, (2nd edn, International Shipping Publications) and Natalia Malashkina (2010)Law Reform in the International Regime of Salvage: The Insurance Perspective (Master's Thesis, Lund University):

$<$ http://lup.lub.lu.se/luur/download?func $=$ downloadFile\&recordOId $=1698365 \&$ fileOId $=1$ 698369>. Accessed 2 January 2013.

${ }^{41}$ Mandaraka-Sheppard, supra note 9, p. 662.

${ }^{42}$ [1866] L.R. 1 A and E 58 at 60. Cited in Mandaraka-Sheppard, supra note 9, p. 663.

43 [1951] AC 820. 
[d]amage to the environment means substantial physical damage to human health or to marine life or resources in coastal or inland waters or areas adjacent thereto, caused by pollution, contamination, fire, explosion or similar incidents. ${ }^{44}$

This aspect of danger to the environment shall be discussed in a detailed manner at a later part of this article.

\subsection{Voluntary Services (Voluntariness)}

In the law of salvage, voluntariness means salvage services rendered without any prior or pre-existing contractual relationship between the parties. ${ }^{45}$ Voluntariness also includes services not done in the line of official duty or for self-preservation. As long as the persons are recognised by law as volunteers and they render salvage services, they are entitled to salvage remuneration. ${ }^{46}$ In The Sava Star, Clarke J. posited that 'there are no rigid categories of salvors. They include any volunteer who renders services of a salvage nature. ${ }^{, 47}$

In the International Salvage Convention 1989, there is no express provision on the rules guiding voluntariness of salvors in salvage operations. ${ }^{48}$ However, it has been contended that Article 17 of the International Salvage Convention 1989 , by implication lays down rules 'for the recovery of salvage and certain qualifications. ${ }^{49}$ The said Article states that: "[n]o payment is due under the provisions of the Convention unless services rendered exceed what can be reasonably considered as due performance of a contract entered into before the danger arose".

Voluntary services in salvage operations can manifest in different circumstances. An example will suffice at this juncture. ${ }^{50}$ Generally, in salvage operations, individuals (for example, ship's master and crew) who have entered agreements with the ship owner prior to the existence of danger are not recognised as salvors. ${ }^{51}$ The reason is because they have an already existing obligation or duty to protect and preserve the ship and cargo. ${ }^{52}$ In The Neptune, Lord Stowell describes a 'volunteer' as: '[a] person who, without any particular

\footnotetext{
${ }^{44}$ Supra note 2.

${ }^{45}$ Mandaraka-Sheppard, supra note 9.

${ }^{46}$ Id., 668.

${ }^{47}$ [1995] 2 Lloyd's Rep, 141. Also cited in Mandaraka-Sheppard, supra note 9, p. 668.

48 Mandaraka-Sheppard, supra note9; Francis D. Rose (2002) Kennedy and Rose: The Law of Salvage (6 ${ }^{\text {th }}$ edn, Sweet \& Maxwell) 243.

49 Rose, Id, p. 242.

50 For an extensive analysis of voluntary services in salvage operations, see MandarakaSheppard, supra note 9, pp. 668-683 and Rose, supra note 48, pp. 243-265.

${ }^{51}$ Mandaraka-Sheppard (n 9).

${ }^{52}$ Ibid.
} 
relation to ship in distress, proffers useful service, and gives it as a volunteer adventurer, without any pre-existing covenant that connected him with the duty of employing himself for the preservation of that ship. ${ }^{, 53}$

However, this rule that individuals with contractual agreements with a ship owner cannot be volunteers is subject to some exceptions. For example, in The Demetrio, the court held that the plaintiffs who were crew members in a vessel that was attacked and abandoned as a result of the orders of the captain were entitled to salvage rewards after they successfully extinguished the fire on the ship at great risks to their safety. ${ }^{54}$

\subsection{Success}

This is the most important element of a salvage operation. Traditionally, if a salvage operation is not successful, the salvor is not entitled to reward. This doctrine is known as the 'No Cure - No Pay' doctrine. Thus, the principles of traditional salvage did not provide for an award for environmental protection where no property was saved. ${ }^{55}$

However, the 1989 Salvage Convention recognizes the need to protect the environment in its provisions. For example, the preamble to the Convention highlights the need to protect the environment. Also, by virtue of Article 13(b) of the International Salvage Convention, the skill and effort of the salvors in preventing or minimising damage to the environment may be a factor in determining a salvage award. Thus, the protection of the environment in salvage operations is an exception to this principle of 'No cure - No pay'. It will be addressed in the fourth section of this article.

\subsubsection{No Cure - No Pay Doctrine}

The justification of the principle is the payment from the salvaged property and not the successful salving of the property. If the vessel in distress is lost or destroyed during the salvage operation, no reward will be awarded. The reason behind the principle is that; the salvage award is paid out of the salved property. If the vessel is destroyed, there would be no basis for any payment to be made to the salvor.

Even if a distressed vessel was rescued from peril at sea, a salvor who claims a salvage reward must prove that he has contributed to the vessel being rescued or salved. This principle was amplified by Lord Phillimorein SS Melanie v. SS

53 (1824) 1 Hagg. 227.

54 (1941) 69 LIL Rep 5.

${ }^{55}$ Gary Beale (2014) 'Environmental Salvage and the 1989 Salvage Convention: Proposed Amendments to the Convention and Difficulties in Quantifying an Environmental Salvage Award' 16 (4) Environmental Law Review 248. 
San Onofre ${ }^{56}$ who stated that "success is necessary for a salvage award. Contributions to that success, or as it is sometime expressed meritorious contributions to that success, give title to salvage reward". ${ }^{57}$

In Marguerite Molinos, a life boat which sent out telegraphs to tugs before going to rescue a distressed vessel was held not to be entitled to a salvage reward. ${ }^{58}$ Here, the onus of proof fell on the life boat crew who had gone out for the purposes of saving lives to prove that they were entitled to the salvage reward against the property in peril or salved. In this case, the life boat crew members were considered not to be salvors. The basis for this decision was that the message in the telegraph was not instrumental in salving the property. This principle can sometimes lead to or perpetuate injustice. ${ }^{59}$ This was exemplified in the '1979 incident of The Aegean Captain and The Atlantic Express. The salvors prevented an oil spill washing up on the beaches of Tobago by towing a badly leaking and ablaze Atlantic Empress far out to sea. The ship then exploded and sank. The salvors received no reward. ${ }^{60}$

In The Benlarig, a vessel which was damaged in a salvage operation was held not to be entitled to any salvage reward. ${ }^{61}$ The master of the salvor vessel proceeded to Gibraltar (wherein the distressed vessel was expected to be towed to) and gave information on the location and condition of the distressed vessel. The efforts of the salving vessel and the information provided by the master to the subsequent salvor were not considered by the court. Thus, the court held that the original salvor was not entitled to a salvage reward in the salvage operations which left the distressed vessel in a more precarious condition. ${ }^{62}$ However, in The Cameillia, the court held that if a distressed vessel is left at a place of safety, the original salvor may be entitled to a salvage reward if the distressed vessel is ultimately salved. ${ }^{63}$

Fortunately, there is an exception to the No cure-No pay principle. The exception is that when a distressed vessel calls for assistance, any vessel that heeds to such a call -even though it does not contribute to the eventual salving of the vessel- is entitled to a salvage award. The rationale for this can be gleaned from the dicta of Lushington in The Undaunted where he stated that ' $t$ t]he engagement to render assistance to a vessel in distress, and the

56 [1925] A.C. 246.

57 Id., 262.

58 [1903] P. 160 cited in NJJ Gaskell and others (1987) ‘Chorley and Giles’ Shipping Law (8edn, Financial Times Management)p. 441.

59 Baughen, supra note 5, p. 287.

${ }^{60}$ Beale, supra note 55, p. 249.

61 (1888) 14 PD 3 cited in Baughen, supra note 5, p. 283.

62 Baughen, supra note 5.

${ }^{63}$ (1883) 9 PD 27 cited in Baughen, supra note 5, p. 283. 
performance of that agreement so far as necessary or far as possible, establish a title to salvage reward'. ${ }^{64}$

The principle of 'No Cure - No Pay' has caused a lot of difficulties to professional salvors in the salvage industry. Salvors were naturally against it, especially since they received no reward after spending money and resources on the salvage operations, despite the salvage operation being unsuccessful. There is also no reward for salvors 'for attending a mid-ocean casualty which did not cause a threat of damage to the environment in coastal or adjacent waters' ${ }^{65}$ This principle of 'No Cure No Pay' has also been somewhat mitigated particularly in the area of environmental protection which shall be explained in further detail in the next part of this article.

\section{Protection of the Environment and Salvage Operations}

There exists an exception against the rigid principle of 'No Cure - No Pay' which relates to the efforts of salvors in preventing damage to the environment from oil laden ships. The problems associated with the salvage of oil laden ships are numerous. For example, oil may escape during salvage operations and the salvors may be held culpable for the resultant environmental pollution. ${ }^{66}$ Furthermore, due to the fear of the environmental impacts of salvage operations involving oil laden ships, it is common practice that governments of coastal states refuse to provide places of refuge to such vessels. Consequently, salvors are left with the option of towing the stricken vessels into the far recesses of the oceans to sink such vessels and this might lead to negative environmental impacts on nearby coastal States. ${ }^{67}$

Salvors may lose the salvage rewards if the salvage operation is unsuccessful and in some instances when the salvage operation is successful, the worth of the salved property may serve as a disincentive for salvors to undertake such (risky)

64 (1860) Lush 92 (Dr Lushington) cited in Baughen, supra note 5, p. 283.

${ }^{65}$ Colin de la Rue and Charles B Anderson (2012) 'Environnemental Salvage - Plus ca change...?' 18 JIML 285. Presently, salvors are entitled to some reward if they successfully prevent damage (from oil laden ships) to the environment.

${ }^{66}$ Baughen, supra note 5.

${ }^{67}$ Archie Bishop (2012) 'The Development of Environmental Salvage and Review of the London Salvage Convention 1989' (2012) 37 Tulane Maritime Law Journal 65. This refusal by governments to provide places of refuge for such vessels is termed the Maritime Leper Syndrome'. Thus, 'coastal States have often refused to grant places of refuge for ships where there was a risk of marine pollution to the offshore environment.' See Yosifumi Tanaka (2014) 'Key Elements in International Law Governing Places of Refuge for Ships: Protection of Human Life, State Interests, and Marine Environment' 45 Journal of Maritime \& Commerce 157, 158. Professor Tanaka also highlights the examples wherein coastal States have refused to provide places of refuge for ships. 
salvage operations. ${ }^{68}$ Arguably, this is because salvors will lose their reward since they have to sink the ship, so they would not be interested in salving a vessel that poses an environmental threat so they are unwilling to help such vessels without an exception to the 'no-cure no pay' principle.

During the last century, larger steamships have been built for the carriage of hazardous materials over the sea. This development has led to many incidents of pollution. The first major pollution incident that occurred was the Torrey Canyon disaster in 1967; it involved a Liberian oil vessel which spilled more than a million barrels of oil as a result of its grounding near the south west of England. ${ }^{69}$ The tugs that were engaged to salve the tanker were unsuccessful. Inevitably, the salvors could not claim salvage because they did not salve the vessel. $^{70}$

A worse incident took place in 1978 in the Amoco Cadiz case which centred on a very large crude carrier (hereinafter 'VLCC'). ${ }^{71}$ During a trip to Rotterdam, its steering gear failed and it broke in half spilling 223,000 tonnes of crude oil. The oil spill spread across 125 miles off the coast of Brittany, destroying fisheries, oyster and seaweed beds, and polluting beaches despite the efforts of 10,000 French soldiers deployed to clean the beach. ${ }^{72}$ According to Redgwell, the Amoco Cadizdisaster gave the impetus for a number of changes in the law of Salvage. ${ }^{73}$ A lot of pressure was exerted by salvors seeking rewards commensurate with their services rendered and coastal states seeking to avoid environmental disasters. ${ }^{74}$ This prompted an immediate response within the Legal Committee of the International Maritime Organisation (hereinafter 'IMO'), which culminated -in 1989- with the adoption of a new International Convention on Salvage ${ }^{75}$ remedying the inherent weaknesses of the International Salvage Convention 1910 (also known as the Brussels Convention) which provided for a strict 'no cure-no pay' salvage regime.

In 1980, as a result of the perceived weaknesses ${ }^{76}$ of the Brussels Convention, the LOF $1980^{77}$ England introduced two concepts. These concepts

${ }^{68}$ Baughen, supra note 5.

${ }^{69}$ Generally see Bishop, supra note 67.

70 Barracuda Tanker Corporation and Union Oil Company of California v United Kingdom of Great Britain and Northern Ireland, Republic of France and States of Guernsey ('The Torrey Canyon') [1969] 2 Lloyd's Law Rep 591.

71 The 'Amoco Cadiz' [1984] 2 Lloyd's Law Rep 304.

$72<$ http://college.hmco.com/history/readerscomp/ships/html/sh_005000_amoco cadiz.htm>. Accessed 9 September 2014.

${ }^{73}$ Catherine Redgwell (1990) 'The Greening of Salvage Law' 14 (2) Marine Policy 142.

${ }^{74}$ Id., 146.

${ }^{75}$ Id., 142.

${ }^{76}$ Due to the 'no cure-no pay' doctrine and non-protection of environment during salvage operations amongst others, the Brussels Convention was deemed a failure by various 
were known as 'enhanced award' and 'safety net.' Both concepts are only applicable in salvage or attempted salvage operations of oil tankers, oil laden ships and tankers with cargo of oil. ${ }^{78}$ The safety net guaranteed the payment of salvors' expenses if the value of the salved property was inadequate to offset the salvage reward and a salvor may also receive an increment of fifteen percent of his expenses if he has succeeded in minimising or preventing environmental pollution. ${ }^{79}$ The safety net was payable by the owners of the ships. A salvor's award is 'enhanced' if he saved maritime property in addition to preventing pollution. However, the concepts were only used in the salvage of oil laden ships.

The uniqueness of these concepts was that they departed from the general rule of 'No Cure - No Pay' by providing incentives to the salvors. These provisions introduced into Article 1 of the Lloyd's Form include a specific agreement on the part of the contractor (salvor) to use his best endeavours to prevent the escape of oil from the vessel while performing the services of salving the vessel, cargo, bunkers and stores. ${ }^{80}$ The 'best endeavours' obligation of salvors is replicated in the recent LOF 2011, the Special Compensation Protection and Indemnity Club Clause (hereinafter SCOPIC) ${ }^{81}$ agreement and clause 4.6 of the Lloyds Standard Salvage and Arbitration Clauses (hereinafter 'LSSA Clauses'). ${ }^{82}$

There is a conundrum as to the "precise meaning of best endeavours" ${ }^{83}$ as encapsulated in the LOF. Rhidian Thomas argues that the 'best endeavours' principle might be subject to diverse interpretations or linguistic formulations such as 'reasonable care', 'due care', 'reasonable endeavours' and 'all reasonable endeavours as amplified in Article 8(1) of the International Salvage Convention $1989 .{ }^{84}$ Unfortunately, courts in the UK are yet to elucidate on 'best

stakeholders in the maritime industry. SeeMalashkina,supra note 40 for an analysis of the Brussels Convention.

${ }^{77}$ Lloyd's Open Form 1980.

${ }^{78}$ Baughen, supra note 5.

${ }^{79}<$ http://www.marine-salvage.com/overview/index.asp?page=no_cure_no_pay.htm $>$. Accessed 2 January 2013.

80 Richard Shaw (1996) 'The 1989 Salvage Convention and the English Law' Lloyds Maritime \& Commercial Law Quarterly 202, 205.

${ }^{81}$ Special Compensation P and I Club Clause (SCOPIC) was developed to mitigate the harshness of art 14 of the 1989 Salvage Convention. SCOPIC will be analysed in the next part of this article.

82 D. Rhidian Thomas (2012) 'Editorial - The best endeavour obligations of salvors' 18 JIML 179.

${ }^{83}$ Ibid.

${ }^{84}$ Ibid. 
endeavours' in salvage cases. Recourse can be found in judicial authorities in other areas of law wherein 'best endeavours' were the focus of UK Courts. ${ }^{85}$

In 1989, the International Convention on Salvage was formally agreed upon in London. It came into force internationally on 1 July 1996. However, it was enacted into English Law by the Merchant Shipping (Salvage and Pollution) Act $1994^{86}$ and this came into force in the UK on 1 January 1995. In the UK, parties can contract out of the Act, or part of it, notwithstanding any contractual provision. ${ }^{87}$ The Salvage Convention is the basis or foundation of the various statutes governing the law of Salvage in the UK.

Under the International Salvage Convention 1989, the key Articles concerned with environmental protection are 1, 8, 12, 13 and 14. Article 1 defines 'damage to the environment' as 'substantial physical damage to human health or to marine life or resources in coastal or inland waters or areas adjacent thereto, caused by pollution, contamination, fire, explosion or similar major incidents.' This definition is different from the one found in Salvage Convention 1910 on the basis that 'damage to environment' has been extended to other hazardous substances apart from oil. ${ }^{88}$ The damage must also have occurred in coastal areas or inland waters or areas adjacent thereto. Arguably if pollution occurs on the high seas, the 1989 Convention will not be applicable.

A major flaw ${ }^{89}$ is the phrase, 'Damage to the Environment' - Substantial Physical Damage' contained in Article 1(d) of the Convention. Brice ${ }^{90}$ posits that it is intended to exclude trivial damage. Thus, it must also be of a "physical character and presumably eliminates cases where the only environmental harm

${ }^{85}$ Ibid. There have been different interpretation of 'best endeavours' by the courts in the UK. For example, in Overseas Buyers Ltd v Granadex SA [1980] 2 Lloyd's Rep 608, 613, the court construed 'best endeavours' as 'doing all that can reasonably be expected', also cited in Thomas (n 82). Also see Rhodia International Holdings Ltd v Huntsman International LLC [2007] 2 ALL ER (Comm) 577. This article adopts the view of Thomas in respect of 'best endeavours' in salvage operations 'will be influenced and shaped by the wider legal and contractual context. For example, under Article 8(1)(c) and (d) of the 1989 Convention a salvor, in appropriate circumstances, is required to seek assistance and accept the intervention of other salvors' Thomas, supra note 82, p. 181

${ }^{86}$ The Merchant Shipping (Salvage and Pollution) Act 1994.

${ }^{87}$ This is by virtue of Article 6, Schedule 11 of the Merchant Shipping Act 1995

${ }^{88}$ The 1910 International Convention for the Unification of Certain Rules of Law Relating to Assistance and Salvage at Sea. Adopted in Brussels, Belgium on 23 September, 1910. $<$ http://www.admiraltylawguide.com/conven/salvage1910.html $>$

${ }^{89}$ Mandaraka-Sheppard, supra note 9, p. 735.

90 Brice, supra note 3, p. 424. 
alleged involves loss of visual amenity, e.g. due to the presence of an unsightly wreck in an area of beauty". 91

However, the Comite Maritime International (hereinafter ' $\mathrm{CMI}$ ') ${ }^{92}$ report provides some insight as to what 'substantial physical damage' refers to. It states thus:

it is intended to make it clear that the definition does not include damage to any particular person or installation. There must be risk of damage of a more general nature in the area concerned. It must be a risk of substantial damage. ${ }^{93}$

In the author's opinion, another flaw is the use of the phrase 'Coastal or Inland Waters' by virtue of Article 1(d) of the Convention. This particular provision in the author's view is too restrictive by expressly mentioning coastal or inland waters; it excludes other types of navigable waters including territorial seas, exclusive economic zones and international waters. Therefore, the Convention is not applicable to exclusive economic zones, high (territorial) seas and international waters amongst others. Furthermore, in the UK, salvage operations in inland waters wherein the vessels are used for inland navigation and salvage operations in inland waters (where no ships are involved) are expressly excluded from the scope of application of the Salvage Convention 1989 by virtue of Schedule 11 of the Merchant Shipping Act 1995. ${ }^{94}$ This restriction or reservation entered by the UK in respect of salvage operations in inland waters will be disincentive in salvage matters brought before English Court or tribunals because such cases will be decided on the basis of English Law and not the Salvage Convention.

Article 8(1) of the1989 Convention, states that a salvor in performing the duties specified in sub-paragraph (a) must carry out the salvage operations with due care and (b) is required to exercise due care to prevent or minimize damage to the environment. Moreover, Article 8(2)(b) states that the owner of a ship

${ }^{91}$ Colin De La Rue \& Charles Anderson (1998) Shipping and the Environment - Law and Practice ( $1^{\text {st }}$ edn, LLP) 578.

92 Cited in Brice, supra note 3, p. 424. The CMI is a non-governmental not for profit international organization established in Antwerp, Belgium in 1897, whose major objective is development and unification of maritime law in all respects. The CMI played major roles in the development and drafting of the extant International Salvage Convention 1989. See CMI website at:

$<$ http://www.comitemaritime.org/Home/0,271,1132,00.html $>$

93 CMI Report to the International Maritime Organisation (IMO) on the draft international convention on salvage approved by XXXII International Conference of the CMI held in Montreal, May 1981. Cited in Brice supra note 3, p. 424.

94 Schedule 11 Part II, s.2 of the Merchant Shipping Act 1995 in Richard Shaw \& Mikis Tsimplis supra note 9, p. 252. 
must also exercise due care to prevent or minimise damage to the environment. Article 12(1) states that successful salvage operations are entitled to a reward. Thus, salvors are supposed to consider the impact of their salvage activities on the environment

It can be contended that a salvor can be held accountable by virtue of Articles 18 and 14(5) if his action of saving a ship causes damage to the environment. Article 18 states that: 'A salvor may be deprived of the whole or part of the payment due under this Convention to the extent that the salvage operations have become necessary or more difficult because of fault or neglect on his part or if the salvor has been guilty of fraud or other dishonest conduct.' Also Article 14(5) provides that: 'If the salvor has been negligent and has thereby failed to prevent or minimise damage to the environment, he may be deprived of the whole or part of any special compensation due under this article.' Baughen argues that '[a]lthough neither Article refers to the possibility that misconduct may expose the salvor to a liability in damages exceeding the amount of any salvage award, their language is not such as to exclude liability under Art 8(1) as an additional consequence of salvorial misconduct.' 95

Articles 13 and 14 form the fulcrum of environmental protection in the Convention. The provisions contain modified versions of the enhanced and safety net awards. ${ }^{96}$ Article 13 lists out the indexes relevant for the calculation of salvage remuneration. According to one of these indexes, the 'skills and efforts of salvors in preventing damage to the environment ${ }^{97}$ would be taken into account in assessing property salvaged by way of an enhanced award. ${ }^{98}$ Arguably, the basis for this provision is to encourage salvors to go and assist ships that threaten the environment. ${ }^{99}$ Thus, the salvors must prove that they actually prevented damage to the environment. ${ }^{100}$ Here, the salvors will not be entitled to any reward under this provision 'if those efforts turn out to be of no avail. $^{101}$

By virtue of Article 13(2), payment of the reward must be in proportion to the respective values of salved property. In the UK, in tandem with the proviso in Article 13(2), Article 4 of Part II, Schedule 11 of Merchant Shipping Act 1995 states - there is no obligation to fix a reward up to the maximum salved value under Article 13 before assessing special compensation to be paid. The underwriters of ship and cargo pay the award accruing from this provision,

\footnotetext{
${ }^{95}$ Baughen, supra note 5, p. 292.

${ }^{96}$ Id., p. 285.

${ }^{97}$ Supra, note 2, art 13(1) (b).

${ }^{98}$ Mandaraka-Sheppard, supra note 9, p. 731.

${ }^{99}$ Bishop, supra note 67, p. 68.

${ }^{100}$ Ibid.

${ }^{101}$ Baughen, supra note 5, p. 286.
} 
notwithstanding that they do not insure a vessel owner for damage to the environment. ${ }^{102}$

Furthermore, Article 13(3) states that the reward shall not exceed the value of the vessel and other property. The value of the reward will be affected by the value of the property salved. ${ }^{103}$ Thus, in cases where there 'is a threat of damage to the environment, values of the salved property are often low and the expense of salvage high. ${ }^{104}$ Arguably, this provision will be a disincentive to salvors in salvage operations.

Article 14 creates a completely new extra-contractual legal right of recovery and it is known as Special Compensation provision. ${ }^{105}$ Special Compensation under Article 14 is said to be:

the most significant modification introduced by the 1989 Salvage Convention in the Law of Salvage and aims at providing incentives for the salvors to get involved in incidents where pollution is threatened, even if there is a risk that very little or no property will be eventually salved. ${ }^{106}$

A salvor is entitled to special compensation under Article 14 (1) if he does not get rewarded under Article 13 in respect of a vessel or cargo which threatened the environment. Under Article 14(2), if a salvor prevented or minimised damage to the environment, the special compensation payable by the owner may be increased to a maximum of thirty percent of expenses incurred by salvor. A tribunal may however further increase it but shall not exceed one hundred percent of expenses incurred by salvor. The expenses incurred by the salvors are termed 'out of pocket' expenses and are guided by the provisions of Article 14(3) of the Convention. It is been contended that 'out of pocket' expenses of salvors are "fairly easily ascertained." ${ }^{107}$ It could entail the 'out of pocket expenses' or monies reasonably incurred by a salvor for the equipment and personnel used in the salvage operation. For example, this may include monies or expenses expended on the hire of salvage equipment or fuel (petrol oil) consumed during the course of the salvage operation. ${ }^{108}$

Article 14(4) states that special compensation shall be paid to the salvor if it is greater than any reward recoverable by the salvor under Article 13. ${ }^{109}$ Here, special compensation is akin to a 'safety net, wherein 'a minimum payment to

\footnotetext{
${ }^{102}$ Bishop, supra note 67 , p. 68

${ }^{103}$ Id., p. 67.

${ }^{104}$ Id., p. 68

${ }^{105}$ Shaw, supra note 80, p. 217.

${ }^{106}$ Shaw \& Tsimplis, supra note 9, p. 257.

${ }^{107}$ Bishop, supra note 67, p. 73.

108 Ibid.

${ }^{109}$ Shaw \& Tsimplis supra note 9.
} 
the salvor, one that took away some of the risk endemic in a "no cure no pay" situation'. ${ }^{110}$ The amount paid as special compensation is the amount of 'assessed compensation that is greater than any salvage reward recoverable (not recovered) under Article 13'. ${ }^{111}$ Under Article 14, only the ship owner is liable for the payment of the special compensation to salvors. This is unlike the scenario under Article 13, wherein the ship, cargo and freight owners among other relevant parties will be liable for the payment of the salvage reward.

In 1991, a tanker, named the ABT Summer caught fire and exploded in the mid-Atlantic off Central Africa. ${ }^{112}$ The salvors who rescued the vessel were held not entitled to special compensation on the basis that the leaking oil did not cause damage to the environment within the meaning of Article 1(d) of Salvage Convention 1989. ${ }^{113}$ In so far as this provision remains, it will serve as a disincentive to salvors in rescuing ships on navigable waters not expressly mentioned in the Convention. Willmer QC posits that having regard to the prevailing wind and current, a ship spilling thousands of tons of oil or noxious chemicals, even though far out at sea, nevertheless threatened to damage marine life or resources in coastal waters or areas thereto. ${ }^{114}$ This view is well-reasoned and in the author's opinion, the correct view.

An inherent weakness in the Convention is 'threatened damage' which is found in Article 14(1) of the International Salvage Convention 1989. Arguably, this phrase is ambiguous, and it has argued whether a real danger or an apprehension of danger is sufficient. If a circumstance was erroneously suspected of being dangerous, one would have to assess whether such error was reasonable or not at the relevant time. ${ }^{115}$ Lloyd's arbitrators treat 'threatened damage' to mean the existence of 'a reasonable apprehension of a danger of such damage at the time of the salvor's initial response. ${ }^{116}$ The probable reason behind this approach is for it to act as an incentive to salvors.

Another disincentive in the International Salvage Convention 1989 is the use of the phrase 'out of pocket expenses.' Article 14(3) of the Convention is very problematic and controversial. The provision states:

Salvor's expenses for the purpose of paragraphs 1 and 2 means out-of-pocket expenses reasonably incurred by the salvor in the salvage operation and a fair

\footnotetext{
${ }^{110}$ Bishop, supra note 67,74 .

${ }^{111}$ Ibid.

112 Cited in Shaw, supra note 80, p. 209.

113 Ibid.

114 John Willmer, (Q.C) 'Salvage and Current Legal Problems' cited in MandarakaSheppard, supra note 9, p. 735.

115 De La Rue \&Anderson, supra note 65, p. 587.

${ }^{116}$ Willmer, J (QC) 'Salvage and Current Legal Problems' (1997) (Public Lecture at London Shipping Law Centre) 13. Also cited in De La Rue \& Anderson, supra note 65, p. 588.
} 
rate for equipment and personnel actually used in the salvage operation, taking into consideration the criteria set out in Article 13, paragraph 1 (h), (i) and (j).

The issue of out-of-pocket expenses arose in the case of the Nagasaki Spirit, where the Court referred to the fair rate of equipment. ${ }^{117}$ At this point, the "issue was whether in assessing a 'fair rate' for the salvor's own craft, equipment, personnel, etc, it was permissible to include a market or profitable rate, or whether the salvor was entitled solely to reimbursement of expenditure". ${ }^{118}$

The House of Lords in affirming the decisions of the lower Courts held that 'out-of-pocket expenses' means a fair rate of expenditure and that profitability is not a criterion in calculating the remuneration. Lord Mustill described the intention of the legislation as follows:

[t]he only structural change in the scheme is that the incentive is now made more attractive by the possibility of obtaining new financial recognition for conferring a new type of incidental benefit. ${ }^{119}$

Salvors were in disagreement with the way in which the remuneration was computed in The Nagasaki Spirit to their detriment for a number of reasons. Salvors contended that the decision in The Nagasaki Spirit disregarded the losses suffered by them in maintaining their (very expensive) specialist equipment in preparation for salvage operations until danger to the environment is eliminated. ${ }^{120}$ The salvors' contention was that: 'such advance capital provision cannot be compensated, in their opinion, without allowance of an element of profit in the fair rate of Article 14 ${ }^{, 121}$ In the author's view, Article 14 of the International Salvage Convention 1989 was inelegantly drafted and this led to its diverse interpretations. Lord Mustill who defended his judgement at a debate held at the London Shipping Law Centre on 19 June 1997averred that the draftsmen of the Convention were to blame because 'he was only the pianist who had to perform the music composed by someone else. ${ }^{122}$

To resolve the challenges induced by the provisions of Article 14 of the International Salvage Convention 1989, the maritime industry (salvors, protection and indemnity clubs, insurers, and other parties) came up with a unique solution; Special Compensation P and I Club Clause (SCOPIC). SCOPIC is a framework or agreement between salvors and ship owners for assessing remuneration based on pre-agreed rates. It can be invoked at any time and the

17 [1997] 1 Lloyd's Law Rep 323.

18 Mandaraka-Sheppard, supra note 9, p. 732.

119 [1997] 1 Lloyd's Rep 323 at 333,

${ }^{120}$ Mandaraka-Sheppard, supra note 9.

121 Id., p. 734.

122 Mandaraka-Sheppard, supra note 9, p. 734. 
parties may contract out of the Convention by incorporating the agreement into the LOF contract, so this dispenses with the assessment procedures in Article 14 of the Convention.

SCOPIC came into effect in August 1999. ${ }^{123}$ One of the distinctive features of the SCOPIC is that ship owners may appoint a Special Casualty Representative (hereinafter 'SCR') who is an independent expert or adviser to the owner and to report on the salvage operations. ${ }^{124}$ The salvage master or salvor is in charge of the salvage operation; however the SCR plays major roles in the operation. For example, the SCR is expected to send daily dissenting report to the ship owner if he does not agree with the daily reports prepared and sent to the ship owner by the salvage master. ${ }^{125}$ Thus, the presence of the SCR is expected to improve transparency in the salvage operation thereby preventing unscrupulous salvors from increasing their remuneration or reward. ${ }^{126}$ However, the major inherent disincentive is that the SCR owe his or her allegiance to the ship owner and not the salvors.

From its inception in 1999 to March 2007, there were 844 LOF cases, of which 165 incorporated the SCOPIC clause and it has been invoked on 182 occasions, however, only five SCOPIC cases have gone to arbitration. ${ }^{127}$ In April 2011, there were 1085 LOF cases; herein, the SCOPIC clause was invoked on 255 occasions and only seven were SCOPIC related arbitration cases. ${ }^{128}$ As

$123<\mathrm{http} / /$ www.marine-salvage.com/overview/index.asp?page=no_cure_no_pay.htm $>$ accessed 13 January 2013. SCOPIC was revised in 2005, 2007, 2011 and 2014. See $<$ http://www.lloyds.com/ /media/files/the\%20market/tools\%20and\%20resources/agency /salvage\%20arbitration\%20branch/scopic\%202014.pdf>. Generally see IlianDjadjev (2015) The SCOPIC clause as a major development in salvage law.' Available at SSRN $2627798<\mathrm{http}: / /$ papers.ssrn.com/sol3/papers.cfm?abstract_id=2627798>

124 Shaw \& Tsimplis, supra note 9. See De la Rue \& Anderson, supra note 65, p. 286, for other significant features of the SCOPIC Clause which include:

'that [the] SCOPIC remuneration is to be paid irrespective of any threat of damage to the environment; detailed tariff rates for craft, equipment and personnel employed in providing salvage services; a [twenty-five] per cent uplift on these amounts to be paid in all cases, regardless of success or failure; arrangements for security to be given for the remuneration due; and provision for rates to be reviewed on a regular basis. Increases have been made on a number of occasions, most recently in 2010.'

${ }^{125}$ Archie Bishop 'The Mystery of the SCOPIC'. <http://www.marinesalvage.com/pdfs/ThemysteryofSCOPICunravelled.pdf> accessed 18 March 2013.

${ }^{126}$ Shaw \& Tsimplis, supra note 9.

${ }^{127}$ Ibid.

${ }^{128}$ See Bishop, supra note 67. Also see LOF Statistics at $<$ http://www.lloyds.com/themarket/tools-and-resources/lloyds-agency-department/salvage-arbitration-branch/lofstatistics>. Accessed: 2 January 2013. For the current statistics on SCOPIC, see $<$ http://www.lloyds.com/the-market/tools-and-resources/lloyds-agency- 
at the end of September 2015, SCOPIC was invoked in 12 out of the 50 new cases in 2015 .

The Fixed Cost Arbitration Procedure (hereinafter 'FCAP') (which started on 3 May 2005) was introduced as an alternative procedure to the established Lloyd's salvage arbitration and it was as a result of complaints about the expenses and complexity of the LOF salvage arbitration. ${ }^{129}$ The falling use of the LOF contract was a factor for establishing the FCAP. ${ }^{130}$

\section{Proposed Reforms}

From the analysis of the problems associated with some provisions regarding environmental protection in the Convention, reforms are urgently required to remedy its inherent weaknesses. Firstly, SCOPIC should be strengthened by making it part of the International Salvage Convention 1989. This can be done by way of an amendment to the Convention by incorporating SCOPIC which is presently a voluntary agreement into it. By making it part of the Convention, it will become mandatory for every ratifying State to abide by it.

The FCAP is an optional guide to arbitrators and therefore the choice between the LOF salvage arbitration and FCAP will be determined by the parties or in the event of default, by the arbitrator. ${ }^{131}$ Accordingly, 'the essence of the new FCAP procedure is that it is a fixed cost arbitration conducted speedily on the basis of evidence only'. ${ }^{132}$ The FCAP is necessary to remedy the deficiencies of the 'LOF', the onus is on the salvage industry to make use of it. The author strongly supports the FCAP as an alternative to the LOF arbitration process.

Article 1 of Salvage Convention 1989 which limits the jurisdiction of environmental salvage to 'coastal or inland waters or areas adjacent thereto' should be reformed. This provision should be rectified by adding the high seas, exclusive economic zones and international waters amongst others. This was the position in the LOF 1980 which extended pollution damage to include those from vessels in the high seas. The present position in the Convention serves as a serious disincentive to would-be salvors in the high seas, because they are not entitled to environmental salvage remuneration in the high seas.

\footnotetext{
department/salvage-arbitration-branch/lof-statistics> Thus, as at the end of September 2015, SCOPIC was invoked in 12 out of the 50 new cases in 2015.

${ }^{129}$ Editorial -'LOF salvage - new fixed cost arbitration procedure (FCAP)' (2005) 11 (3) JIML169. Thus, the FCAP 'allows for a documents-only arbitration process.' Djadjev supra note $123, \mathrm{p} .3$.

130 Id., p. 169.

131 Ibid.

132 Ibid.
} 
Historically, ships can enter the nearest ports, bays, or other waters located within the sovereignty of a coastal state to avoid storms and repairs, ${ }^{133}$ and under customary international law foreign vessels in distress have a right to seek refuge in the ports or waters that were not the intended destination. ${ }^{134}$ Unfortunately, this rule is not the norm in salvage operations affecting the environment. In the Irish case of $M V$ Toledo, the court held that even though the right to refuge exists, a state has the power to legally refuse the entry of a ship if it poses significant harm to the state or its citizens. ${ }^{135}$ Thus, refusing entry to such ships in distress may lead to such ships discharging their oil waste in the high seas, thus leading to severe environmental consequences for other nearby States.

To mitigate this problem, the IMO has adopted two resolutions to the effect. ${ }^{136}$ The first is Resolution A.949 (23) Guidelines on Places of Refuge for Ships in Need of Assistance ${ }^{137}$ which is used when a ship is in need of help but safety of life is not involved. It recognises that if a ship is involved in an accident, the solution is to transfer its cargo and bunkers and repair it at the place of refuge. ${ }^{138}$ States might object to it on the basis of environmental and economic reasons. ${ }^{139}$ For example, if the environmental and economic impact of such vessels on the country of refuge is deemed to be detrimental to the interests of that country, it may deny (the stricken vessel) entrance to its waters. This is because tourism, vegetation and animals in such waters will be negatively affected if the sea shore or coastal area is affected by oil pollution. In The Prestige ship disaster, the Spanish Government ordered it away from its coast ${ }^{140}$ which unfortunately led to worse pollution occurring than earlier feared. Thus, States make such decisions on a case-by-case basis and 'consideration would need to be given to balancing the interests of the affected ship with those of the environment'. ${ }^{141}$

133 Aldo Chircop (2002) 'Ships in Distress, Environmental Threats to Costal States, and Places of Refuge: New Directions for an Ancien Regime? 33 (2) Ocean Development \& International Law 207, 208.

${ }^{134}$ Id., p. 209.

${ }^{135}$ Cited in ibid p. 215.

${ }^{136}<\mathrm{http} / / /$ www.imo.org/Safety/mainframe.asp?topic_id=746>

${ }^{137}$ Resolution A. 949 (23). Adopted on 5 December 2003 (Agenda item 7) Guidelines on Places of Refuge for Ships in Need of Assistance. Text of the resolution is available online at the IMO website at:

$<$ http://www.imo.org/blast/blastDataHelper.asp?data_id=9042\&filename=949.pdf $>$

${ }^{138}$ Chicop, supra note 133.

139 Ibid.

${ }^{140}$ Shaw \& Tsimplis, supra note 9.

141 Aleka Mandaraka-Sheppard (2007) Modern Maritime Law (2nd edn, RoutledgeCavendish) p. 717.Thus, Allison argues that a new international convention is required to 
The second resolution is A.950 (23) Maritime Assistance Services (MAS) ${ }^{142}$ which advises that all coastal States should establish a Maritime Assistance Service (hereinafter 'MAS'). The functions of MAS would be to receive reports, monitor a ship situation and it will "serve as a point of contact between those in salvage operations undertaken by private facilities if the coastal State considers that it should monitor all phases of the operation". ${ }^{143}$

The major flaw of the two Resolutions is that they are non-binding on States; thus they are mere recommendations. These guidelines may be used in the future as a basis of harmonising State policies on places of refuge. For example, it can be contended that these aforementioned guidelines are the inspiration for the place of refuge in salvage operations in the UK. In the UK, the Secretary of State's Representative (hereinafter 'SOSREP') has 'the powers to oversee and control and intervene in salvage operations within UK waters involving vessels or fixed platforms where there is significant risk of pollution. ${ }^{144}$

The SOSREP is appointed by the Secretary of State on behalf of the UK Government. ${ }^{145}$ The powers of the SOSREP are enunciated in Schedule 3A of the Merchant Shipping Act 1995 as amended by the Marine Safety Act 2003. ${ }^{146}$ The SOSREP or the Maritime and Coastguard Agency have the task of directing

provide certainty as to the rights and obligations of parties involved in incidents posing potential threats to the marine environment. See Simon Allison (2015) 'Salvage Companies and Protection of the Marine Environment: Time to Pay the Piper?' (MPhil Dissertation submitted to the University of Western Australia).

142 Resolution A. 950 (23). Adopted on 5 December 2003 (Agenda item 17) Maritime Assistance Services (MAS)

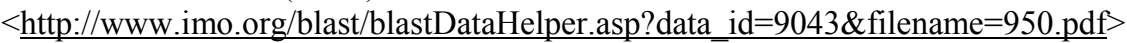
accessed 5 December 2014. In 2009, the CMI developed a Draft Instrument on Places of Refuge. This Declaration seeks to clarify or adumbrate the rights and obligations of coastal States in providing places of refuge $<$ http://comitemaritime.org/Places-ofRefuge $/ 0,2733,13332,00 . h t m l>$. According to Allison, supra note 141 , p. 116 a major incentive in the CMI Declaration is that it 'guarantees salvors a right of compensation if they fail to earn a reward due to the coastal State's unreasonable refusal of a place of refuge.' However, the CMI Declaration of places of refugee was not popular amongst the IMO Legal Committee and coastal States. Thus, it is highly unlikely that CMI Draft Instrument on Places of Refuge will be adopted. Generally see Allison supra note 141 and Simon Baughen (2012) 'Maritime Pollution and State Liability' in Baris Soyer and Andrew Tettenborn (eds) Pollution at Sea: Law and Liability (Informa) p. 247.

143 Ibid.

${ }^{144}$ Shaw \& Tsimplis, supra note 9, p. 269.

145 Ibid.

${ }^{146}$ Shaw \& Tsimplis, supra note 9. 
stricken ships to appropriate places of refuge in the UK. ${ }^{147}$ The SOSREP has had positive impacts on place of refuge in salvage operations in the UK. For example, in 2007 when the MSC Napoli which was affected by heavy flooding while transiting the English Channel on its way to South Africa was directed by the SOSREP - in consultation with the French authorities- to ground the ship on the beach line by Portland. ${ }^{148}$ This prompt action of the SOSREP resulted in minimal pollution and no loss of life was recorded. ${ }^{149}$ The action taken by the SOSREP was universally applauded by relevant authorities in the salvage industry especially representatives of the European Commission. ${ }^{150}$

Another proposed reform in the area of port of refuge is to create maritime or regional (national) zones. There should be a system of regional areas (ports, safe havens) where distressed ships can seek refuge and receive necessary services in relation to human, vessel and environmental safety. ${ }^{151}$ Zoning 'is needed together with supporting infrastructure, contingency planning, risk assessment, and other services to enable informed and effective case-by-case responses'. ${ }^{152}$ In the European Union, places of refuge are actively encouraged. The European Directive 2002/59/EC ${ }^{153}$ establishes a system wherein national authorities in Member States are expected to collect information or data on ship movements and incidents and receive applications for entry into places of refuge. ${ }^{154}$ Here, each State has the powers to designate the suitable places of refuge by virtue of Article 20 of the Directive. ${ }^{155}$

${ }^{147}$ Dennis Bryant, (2013) 'Places of Refuge' (February 2013 edition of Maritime Reporter \& Engineering News) <http://www.marinelink.com/news/places-refuge-of351560.aspx>. Accessed 3 March 2013.

148 Ibid.

149 Ibid.

${ }^{150}$ Mandaraka-Sheppard (2007) supra note 141.

${ }^{151}$ Chircop, supra note 133, p. 221.

152 Ibid.

${ }^{153}$ Directive 2002/59/EC of the European Parliament and the Council of 27 June 2002 establishing a Community vessel traffic monitoring and information system and repealing Council Directive 93/75/EEC. $<$ http://eurlex.europa.eu/LexUriServ/LexUriServ.do?uri=OJ:L:2002:208:0010:0010:EN:PDF>. Accessed: 3 March 2013.

${ }^{154}$ Shaw \& Tsimplis, supra note 9.

${ }^{155}$ Art 20 of the European Directive 2002/59/EC states:

'Member States, having consulted the parties concerned, shall draw up, taking into account relevant guidelines by IMO, plans to accommodate, in the waters under their jurisdiction, ships in distress. Such plans shall contain the necessary arrangements and procedures taking into account operational and environmental constraints, to ensure that ships in distress may immediately go to a place of refuge subject to authorisation by the competent authority. Where the Member State considers it necessary and feasible, the 
However, this Directive is not fool-proof. It has been criticised on the basis that - ports have no reasonable incentive to admit ships in distress. The matter is dominated by legal uncertainty and this increases the risk of disasters occurring within Maritime Lepers. ${ }^{156}$ To mitigate the harshness of the Maritime Leper syndrome, it has been suggested that an international convention that localises the interests of the stakeholders in the salvage industry be sought or enacted. ${ }^{157}$ In the author's view, the two IMO Resolutions ${ }^{158}$ on places of refuge should serve as the foundation of any international convention that will be developed in the future to resolve the problem of the appropriate places of refuge in salvage operations and the interests of countries. This will also help in protecting the environment during salvage operations.

Furthermore, due to the weaknesses in the international salvage regime with regards to the environment, scholars and stakeholders have advocated for the creation of a separate and distinct environmental salvage award. ${ }^{159}$ The International Salvage Union (ISU) contends that provisions of the International Salvage Convention on the environment should be amended because it does not adequately reward salvors for their efforts in protecting the environment in salvage operations. ${ }^{160}$ Thus, the ISU believes that the creation of a separate salvage award will result in significant awards for the salvors reflecting the benefit they provide. ${ }^{161}$ On the other hand, some stakeholders including the P\&I Clubs (Protection \& Indemnity Clubs who insure the liabilities of ship-owners) have argued that 'the Special Compensation P\&I Clause (SCOPIC) adequately remunerates a salvor and that, should a separate salvage award be created, it would be problematic to quantify. There is also the question of who should fund such an award.' 162

plans must contain arrangements for the provision of adequate means and facilities for assistance, salvage and pollution response.'

156 E. Van Hooydonk, 'The Obligation to offer a place of refuge to a ship in distress' in the Work of CMI, Part II, 2004. Cited in Mandaraka-Sheppard (n 9) 718.

The term, 'maritime lepers is used for 'stranded or endangered vessels abandoned by their owners, feared by the coastal communities and avoided by the salvors' (Mišo Mudrić (2013), The Professional Salvor's Liability in the Law of Negligence and the Doctrine of Affirmative Damages, Lit Verlag, p. 42.

${ }^{157}$ Van Hooydonk ibid

158 Resolution A.949 (23) Guidelines on places of refuge for ships in need of assistance and A.950 (23) Maritime Assistance Services (MAS).

159 Beale, supra note 55; International Salvage Union 'Position Paper on the 1989 Salvage Convention' p. 1. Available online at: http://www.marinesalvage.com/environmental/ISU\%20Final\%20Position\%20Paper.pdf; Also cited in Beale, supra note 55, p. 249.

${ }^{160}$ ISU, Ibid.

161 Ibid.

${ }^{162}$ Beale, supra note, 55, p. 249. 
Thus, in 2012, the National Maritime Law Associations which includes the members of the CMI took part in the fortieth Anniversary Conference of the CMI in Beijing, China. ${ }^{163}$ One of the themes at the Conference was a review of the International Salvage Convention 1989 as enunciated by the International Salvage Union (hereinafter 'ISU'). ${ }^{164}$ The major aim of the ISU was the creation of a new environmental salvage paradigm wherein the requirement of 'the tribunal or arbitrator" was "to make an appraisal of the extent and cost of damage to the environment which would have occurred if the ship had not been salved.' ${ }^{165}$ This was in contradistinction to the prevailing connotation of environmental protection in salvage operations wherein arbitrators assess the dangers to the ships or cargo from which the salvors have rescued them which requires 'an appraisal of what did not happen, but which might have happened. ${ }^{166}$ The Conference delegates emphasised the difficulties in computing damages to the environment in hypothetical scenarios and its financial implications; thus it was the consensus at the Conference that protection of the environment -as currently enshrined in the International Salvage Convention 1989- should be maintained.

\section{Conclusion}

Strictosensu, there is no pure environmental salvage award presently in the International Salvage Convention 1989. However, the Convention ascribes some marginal protection to environment in salvage operations. Notwithstanding the promotion of environmental protection as enshrined in the International Salvage Convention, many environmental disasters by ships and other similar vessels still occur till date. For there to be a full environmental salvage regime, the International Salvage Convention 1989 should be comprehensively reformed. Notwithstanding the recent Beijing Conference, the International Salvage Convention 1989 and the environmental protection paradigm remain bedevilled with structural and institutional shortcomings.

The question at the core of this paper was whether the provisions of the International Salvage Convention 1989 adequately incentivise salvor's efforts in the course of conducting salvage operations to prevent, or at least reduce pollution damage? Arguably, this objective would appear to be taken for granted due to the decision taken at the CMI's Beijing Conference in 2012 to reject the notion of a separate environmental salvage award on the grounds that the

\footnotetext{
${ }^{163}$ See the proceedings of the conference at the CMI Beijing conference page at $<$ http://www.cmi2012beijing.org/dct/page/1>. Accessed 5 January 2013.

${ }^{165}$ Richard Shaw (2012) 'International and Regional Organizations: Review and Analysis Report of Beijing Conference 15-19 October 2012' 18 JIML 316.

${ }^{166}$ Ibid.
} 
salvors' had not made out a sufficiently persuasive case for the amendment of the Convention to accommodate such a separate award. Thus, the Beijing Conference is not a light at the end of the tunnel for environmental protection or the development of a separate or distinct environmental salvage award.

As Professor Tanaka duly noted -in relation to the places of refuge conundrum - the Prestige accident in 2002 demonstrates that "sending a ship requiring a place of refuge back to the sea entails the risk of causing serious marine pollution". ${ }^{167}$ And this damages "the offshore environment of multiple coastal States and the high seas. It must [thus] be stressed that places of refuge for ships also relate to a common interest of the international community with regard to marine environmental protection". ${ }^{168}$

${ }^{167}$ Tanaka supra note 67, p. 158 . For the potential liability of coastal States that refuse to provide places of refuge, see Sussane Storgårds (2012) Coastal State Intervention in Salvage Operations: Obligations and Liability Toward the Salvor. (Master's Thesis submitted to the University of Tromsø) pp. 38-39. 168 Ibid. 